\title{
Visual disturbance as primary symptom of pituitary apoplexy in pregnancy
}

Norazlida Binti Ibrahim ${ }^{1,2}$, Raja Norliza Binti Raja Omar ${ }^{1}$, Mae-Lynn Catherine Bastion $^{2}$

${ }^{1}$ Department of Ophthalmology, Hospital Melaka, Ministry of Health, Melaka, Malaysia; ${ }^{2}$ Department of Ophthalmology, Faculty of Medicine, Universiti Kebangsaan Malaysia, Kuala Lumpur, Malaysia

\section{Abstract}

Pituitary apoplexy in pregnancy is a potentially fatal condition caused by acute ischaemic infarction or haemorrhage of pre-existing pituitary adenoma or within a physiologically enlarged pituitary gland. It has a wide spectrum of clinical presentations ranging from a mild headache to sudden collapsed. Here, we report a life-threatening case of pituitary apoplexy in a non-functioning pituitary macroadenoma occurring during pregnancy that presented with bilateral blurring of vision. Visual field showed bitemporal superior quadrantanopia. Urgent non-contrast brain MRI revealed an acute expansion of a hemorrhagic pituitary lesion complicated with local compression to the optic chiasm. The patient underwent an uneventful right supraorbital craniotomy and excision of the tumour under general anaesthesia with no foetal loss. The repeated visual field at 2 weeks after surgery showed recovering visual field defect. Hence, early neurosurgical intervention is advisable to prevent mortality and morbidity due to permanent visual field loss.

Keywords: pituitary apoplexy, pregnancy, visual field defect

Correspondence: Norazlida Binti Ibrahim, MD, Department of Ophthalmology, Hospital Melaka, Jalan Mufti Haji Khalil, 75400 Melaka, Malaysia. 


\section{Gangguan penglihatan sebagai simtom primer pituitary apoplexy semasa hamil}

\section{Abstrak}

Apoplexy pituitari semasa hamil merupakan keadaan yang berpotensi membawa maut. Ia terjadi akibat infarksi iskemia akut atau pendarahan sama ada di adenoma pituitari sedia ada atau di dalam kelenjar pituitari yang besar secara fisiologi. Apoplexy pituitari mempunyai spektrum klinikal yang luas; dari sakit kepala ringan hingga tidak sedarkan diri secara tiba-tiba. Satu kes apoplexy pituitari dalam makroadenoma pituitari yang tidak berfungsi (non-functioning pituitary macroadenoma) semasa hamil, dilaporkan disini. Pesakit mengalami kabur penglihatan secara bilateral dan hasil ujian medan penglihatan menunjukkan superior kuadrantanopia bitemporal. MRI otak tanpa kontras menunjukkan peningkatan saiz adenoma pituitari dengan pendarahan yang menghimpit kiasma optik. Pesakit telah menjalani surgeri 'supraorbital craniotomy' pada sebelah kanan dan pembuangan tumor di bawah bius am, tanpa kehilangan foetal. Ujian medan penglihatan yang dijalankan 2 minggu selepas surgeri menunjukkan defek medan penglihatan beransur pulih. Oleh itu, intervensi awal surgeri neuro adalah dicadangkan untuk menghalang kehilangan medan penglihatan kekal bagi kes sebegini.

Kata kekunci: apoplexy pituitari, gangguan medan penglihatan, kehamilan

\section{Introduction}

Pituitary apoplexy in pregnancy is an uncommon but life-threatening medical condition. It requires a multidisciplinary approach to reduce the morbidity and mortality rate. Visual disturbance is one of the most common presentations and bitemporal superior quadrantanopia is the typical visual field defect. Another ocular clinical feature is ophthalmoplegia, which is caused by local compression to the cavernous sinus. 

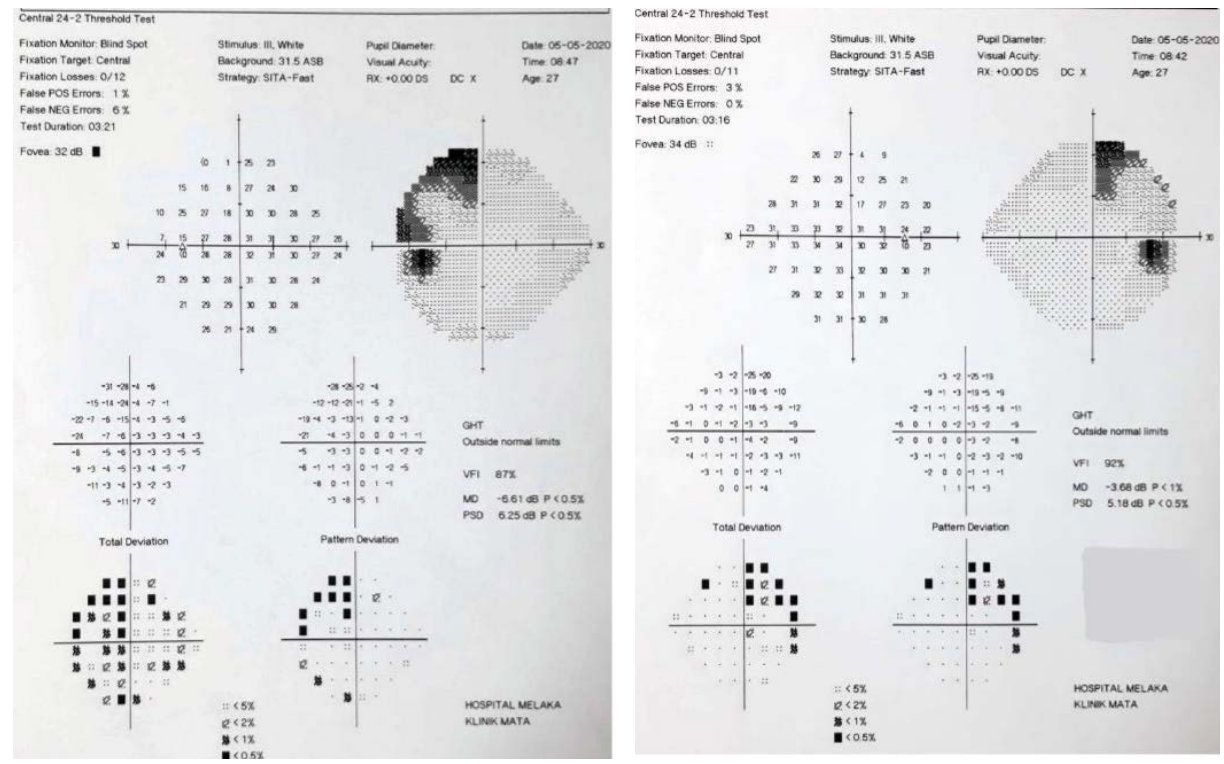

Fig. 1. Left $(a)$ and right $(b)$ visual fields at presentation.

\section{Case presentation}

A 27-year-old woman at 24 weeks of pregnancy with underlying non-functioning pituitary macroadenoma presented with generalized and progressively worsening bilateral blurring of vision for 1 month. There were no other neurological symptoms. On examination, vision was 6/9 OU. Visual field showed bitemporal superior quadrantanopia with no relative afferent pupillary defect (Fig. 1). No papilledema was seen on fundus examination. Other neurological examinations were unremarkable. The vital signs were stable. Urgent non-contrast brain MRI revealed an acute expansion of a hemorrhagic pituitary lesion complicated with local compression to the optic chiasm (Fig. 2). Urgent neurological, endocrine, and obstetric referrals were made. She was started on intravenous hydrocortisone $50 \mathrm{mg}$ every 8 hours and regular monitoring of haemodynamic status. She underwent an uneventful right supraorbital craniotomy and tumour excision under general anaesthesia with no foetal loss. Repeated visual field 2 weeks after surgery showed recovery in the visual field defect with no further deterioration in vision (Fig. 3). 

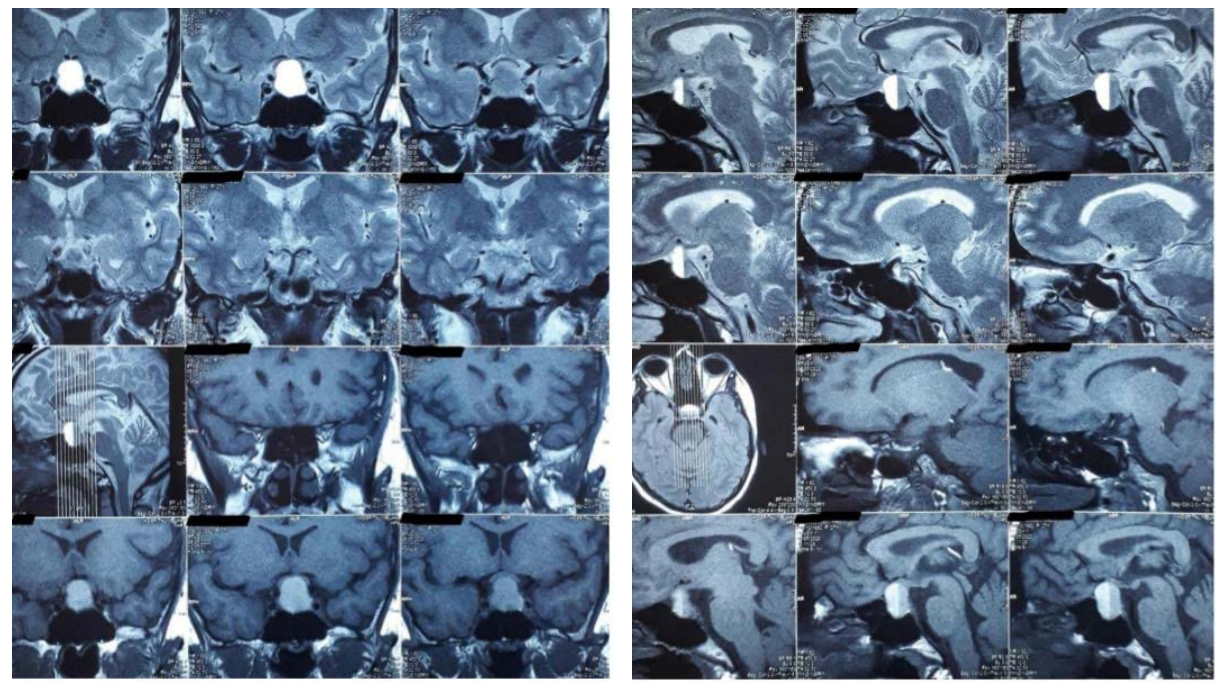

Fig. 2. Coronal ( $a$ ) and sagittal (b) views of brain MRI.
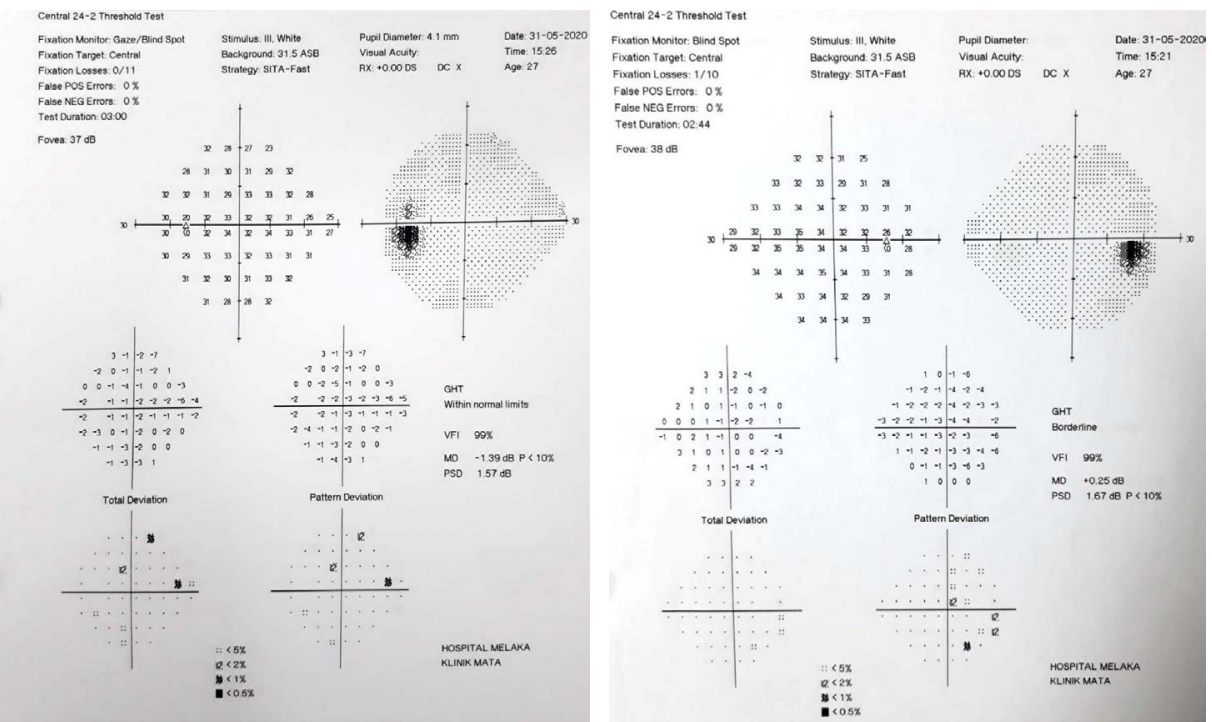

Fig. 3. Left (a) and right (b) visual fields 2 weeks after surgery. 


\section{Discussion}

Pregnancy is one of the known risk factors for developing pituitary apoplexy. Other risk factors include oestrogen replacement therapy, coagulopathies, diabetes mellitus, hypertension, and head trauma., ${ }^{1,2}$ The pituitary gland undergoes remarkable physiological adaptations and haemodynamic changes to meet the increased metabolic demands of pregnancy and foetal development, as evidenced by an MRI study showing an increment of up to $45 \%$ in pituitary volume during the first trimester. ${ }^{3}$ Increased number of lactotroph cells and physiological elevation of serum prolactin also contribute to pituitary enlargement. ${ }^{1}$ Despite having higher energy requirements, it has a limited expression of angiogenic factors, therefore a limited blood supply. Hence, pituitary adenomas have a greater likelihood to bleed and undergo infarction. ${ }^{4}$

The presenting symptoms of pituitary apoplexy in pregnancy include sudden and severe headache (97\%), visual disturbances (61\%), and nausea (33\%), with 24 weeks' gestation as median time of presentation. ${ }^{1}$ The more severe clinical features associated with pituitary apoplexy include altered level of consciousness $(22 \%)$ and autonomic dysfunction due to adrenal insufficiency, which can be life threatening. ${ }^{1}$ In this case, the patient presented with visual complaints as the primary symptom as evidenced by bitemporal superior quadrantanopia defect in visual field examination. Another common ocular clinical feature of pituitary apoplexy is ophthalmoplegia.

Early surgical intervention is indicated in patients with persistent and deteriorating visual field defects. ${ }^{5}$ Compression to the optic chiasm may lead to reversible or irreversible injury. Reversible mechanisms include impedance of axoplasmic flow, conduction blockage, and demyelination. Persistent and severe compression may lead to irreversible axonal fibre degeneration. ${ }^{6}$ In this case, the patient underwent supraorbital craniotomy and tumour excision 1 week after presentation. Repeated visual field 2 weeks after surgery showed visual field defect recovery, suggesting reversible injury due to local compression of the optic chiasm. In some cases, ongoing recovery of visual field defects over the years may be explained by the likelihood of neural plasticity. ${ }^{6}$

\section{Conclusion}

Early symptom recognition and a multidisciplinary approach are crucial in managing pituitary apoplexy in pregnancy prevent mortality and morbidity due to permanent visual field loss. 


\section{Declarations}

\section{Consent for publication}

The patient provided informed consent for the use of the clinical images and information contained in this case report.

\section{Competing interests}

None to declare.

\section{Funding}

None to declare.

\section{Acknowledgements}

None to declare.

\section{References}

1. Sopie G, Florence W, Marie-Josee B, et al. Pituitary apoplexy in pregnancy: A case series and literature review. Obstet Med. 2015; 8(4):177-183.

2. Salam R, Manash PB. Pituitary Apoplexy. Indian J Endocrinol Metab. 2011;15(Suppl3): 188-196.

3. Gonzalez JG, Elizondo G, Saldivar D, et al. Pituitary gland growth during normal pregnancy: an in vivo study using magnetic resonance imaging. Am J Med. 1988;85:217-220.

4. Adriana A, Francesco F, Filippo FA, et al. Multidisciplinary Management of Pituitary Apoplexy. Int J Endocrinol. 2016;2016:7951536.

5. Rajasekaran S, Venderpump M, Baldeweg S, et al. UK guidelines for the management of pituitary apoplexy. Clin Endocrinol. 2011;74:9-20.

6. Arif A, Imad K. The impact of Surgical Timing on Visual Outcome in Pituitary Apoplexy: Literature review and case illustration. Surg Neurol Int. 2017;8:16. 